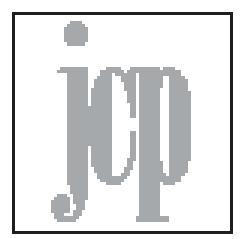

\title{
Performative Subalternity and Positionality in Mohsin Hamid's The Reluctant Fundamentalist
}

\author{
Zachary Bordas \\ Department of English | University of Georgia \\ zacharybordas@uga.edu
}

\section{ABSTRACT}

In this paper, I investigate how Muslim identity came under literary and political scrutiny after the attacks of 9/11. I explore the development and struggle for agency of those marginalised in post-9/11 America, as discussed in Mohsin Hamid's The Reluctant Fundamentalist (2007). By focusing on Hamid's protagonist Changez, a Pakistani immigrant, I expand on Gayatri Spivak's definition of the subaltern. I investigate how borders play a vital role in the process of marginalisation, and my examination of border crossings paves the way for a different sort of postcolonial existence, which I call the performative subaltern. Hamid provides insights into the repercussions of marginalisation to show how it sabotages the possibility of a cosmopolitan existence. Once moving into the position of the performative subaltern, Changez becomes the victim of growing Islamophobia in the US. The novel demonstrates how politics and cultural awareness affect not only one's conceptualisation of race, but how racial and religious identity hinders one's ability to become an acculturated immigrant. Changez represents this shift from a pre9/11 to a post-9/11 world, in which racism acts as a politics of exclusion. Changez's positionality, in the novel and in the world, directly influences how he performs as a subaltern: either to consent or radicalise. In post-9/11 America, Changez faces ostracisation as other; however, when he leaves the US to become a university professor in Pakistan, he twists Spivak's subaltern principle (that underprivileged, disadvantaged segments in society have no voice for change) by developing a political voice of protest, but only after he moves beyond the borders of the United States.

Keywords: Islam, marginalisation, subaltern, performance, trauma 
Since the publication of Mohsin Hamid's The Reluctant Fundamentalist (2007), scholars have thoroughly scrutinised the novel's representation of the marginalisation of Muslims living in the United States after 9/11. Due to the amount of research on this topic, one might suggest the lack of need for further criticism on this matter. This essay, however, posits that there remain a few gaps left to examine, such as the relationship between performance and mobility as a response to discrimination. By looking at The Reluctant Fundamentalist, I suggest that the positionality of a body, regarding borders, creates an opportunity to perform subalternity, even when a person cannot be one by definition. In a 2015 interview about his novel, Hamid poses an intriguing question about this issue: "To what extent do we create conditions where people who feel they belong to two different [nationalities] are encouraged to accept themselves as mongrel, as both, [but] are instead encouraged to pick one, and in fact are asked to pick one or expected to pick one?" ("Q\&A"). Acculturation, or its opposite, the rejection of one's heritage, is complicated when the issue of both physical and psychological borders of nationalism, global economy, and religious diversity threaten to fragment a person's sense of belonging. Hamid, later in the interview, further discusses border crossing based on his own experience: "I think there is also a group of people, in a way like Changez in the novel, who feel dividedthat feel they are of two worlds," he adds, "why don't I just act like myself? I think there is enormous pressure on us to, in a way, to pick sides: to say that I am two things; that is wrong - I should be one thing" ("Q\&A"). This pressure, "to pick sides," forces a person, one who belongs to several identity categories, to choose which story he or she adopts as his or her own. This person must either accept a nationalistic view of his or her personhood, or this individual must decide to align with his or her cultural heritage. In this paper, I examine how American nationalism/patriotism effectually facilitates the opportunity for performative subalternity. We recall Spivak's definition of the subaltern as one who has no voice for change, one who is not aware of being a subaltern, and one who has no access to the culture of imperialism because of his or her position in society (Spivak 40; Ethics 107; Kock 46). From this understanding of the subaltern, I propose to look at fragmented identities by twisting Spivak's definition of subalternity through position and performance, which Hamid gestures toward in The Reluctant Fundamentalist.

When Spivak theorises about the subaltern, she focuses on how a person's position in society relates to how he or she is viewed by that society. She discusses that some people are placed in the margins of society by fabricated narratives 
stemming from the elite groups of a society. Spivak's famous essay "Can the Subaltern Speak?" uses the example of Bhubaneswari Bhaduri's suicide as the platform to question the concept of subalternity. She, after a long explanation concerning the event and nature of Bhaduri's death, explains that Bhubaneswari is "not a 'true' subaltern;" she is "a woman of the middle class, with access, however clandestine, to the bourgeois movement for independence" (Spivak 64). Readers, therefore, must look earlier in her essay to understand why Spivak does not consider Bhubaneswari a "true" subaltern. In her deconstruction of Marx, she warns against confusing the repression of those who are marginalised (those in the periphery without access to economic surplus value) with subalternity (those who are unaware of their repression). For her, one must resist the temptation to classify someone by a political context via the "inner dynamics of Vertretung," or by an "economic context" via the "Darstellung" (33). This implies that a person's political involvements (in relation to class-struggle) are not the sum total of that person's identity. Likewise, she argues that a subaltern is one positionally unaware of his or her class-struggle via elitist politics. The subaltern, therefore, is not a political or class-conscious struggle over "power and desire;" instead, the issue revolves around interpellation (how a person is shaped by the ideologies of institutions without their knowledge), and by the elite who control various social norms (33-4). Bhubaneswari fights for independence, which is why she is not a "true" subaltern in Spivak's mind; however, she became subaltern "posthumously, by other women" who misread her death (40). This means, "there is no unrepresentable subaltern subject that can know and speak itself" (40). One may wonder, then, to what extent can the term subaltern extend?

Spivak, in an interview with Leon De Kock, differentiates the subaltern from oppression that is based on money or race. Discrimination, for her, is not the same as subalternity; in other words, the oppressed can speak within the confines of "hegemonic discourse," and they do so because they are aware of the discrimination against them (Kock 46). These persons, consequently, cannot be a 'true' subaltern; they speak in the political language of their oppressors. Their speech, nonetheless, does not guarantee any substantial changes. By comparison, a subaltern "has limited or no access to the culture of imperialism (45). Therefore, a major point that I complicate is whether or not subalternity is formative or concrete in nature; specifically, can a person move from a position of hegemony into that of the subaltern? I question whether a person can be considered subaltern if he or she becomes aware of his or her subalternity. I, for the rest of this essay, argue that economic and social trauma gestures towards a performative type of 
subalternity, which is to say that people can adopt a subaltern mentality without actually being one. Furthermore, I discuss the role that trauma plays in the type of subalternity that is performed. Accordingly, I examine how a person, who is economically stable but racially traumatised, may adopt and perform different characteristics of subalternity, which is based on the positionality of his or her body as it moves between national borders. This mobility questions the nature of having a homeland; in other words, does a traumatic event muddle one's sense of home? In the same vein, I question whether or not one's identification with a certain location permits that person to have a voice, as well as locations effect on one's ability to speak?

The Reluctant Fundamentalist is an innovative novel that, through terrorism and the closing off of national borders, shows the possible genesis of a subaltern group, which, as Esra Santesso mentions, goes against Spivak's idea that a person is born subaltern and cannot choose to adopt the true sense of the position (101). Hamid's novel, however, is curious because its primary interest concerns the rise and the direct effects of Islamophobia in a post-9/11 world. Alaa Alghamdi suggests that this fear became so engrained in western minds that "it warrants its own distinct label, 'Islamophobia'” (57). This phobia is fascinating because it is directed at people believed to be Muslims (as opposed to the faith itself). I, therefore, am interested in how this fear, from an elite American perspective, alters the representation and voice of Muslims living in the US after 9/11. I discuss this delineation through the performativity of those marginalised in post9/11 America.

The novel's protagonist, Changez, is a Pakistani immigrant who leaves his homeland to pursue the American dream. Initially he enjoys the privileges of the western world, yet by the end of the novel is repressed by Islamophobia. Changez, after graduating from Princeton, quickly rises to the top of the corporate world. He, after college, moves to New York City where he works as an analyst for Underwood Samson, which many critics note is a play on words for US (Balfour 215; Gasztold 19; Morey 140). Since he is able to achieve multilayered success, despite his ethnicity and nationality, Alghamdi argue that Changez is not a subaltern (53). Similarly, Alghamdi posits that Changez's prosperity would have continued unscathed had he decided to stay in the US. He states, "We are even asked to explore the somewhat startling notion that America is not inherently a racist society, as demonstrated by its willingness to elevate those of nonwhite races" (53). I agree with Alghamdi, as far as the first part of the novel is concerned; however, I believe a clear divide is present after the events of 9/11 
that directly contradict his claim. I consent that Changez's education and financial standing are why he is not a 'true' subaltern. Nonetheless, I will demonstrate that his fall from economic success, into the depths of voiceless want, creates an opportunity for a performative subalternity. In other words, Changez enjoys the spoils of hard work and economic gain before the terror attacks on New York City, which suggests that he has no reason to assume that his attempts at acculturation will be thwarted by $9 / 11$. Conversely, after 9/11' elite groups of people pump patriotism and anti-Islamic propaganda throughout the media, which, as a consequence, hinders Changez's access to the economic benefits of working and living in America. This denial to interact with the majority culture, and even more his ability to fully acculturate as an American citizen, emotionally thwarts his ability to change the growing pessimism and misunderstanding about Islam and Pakistan. This dichotomy, between those who do the profiling and those who are unable to erase their profile, is where I argue the performative subaltern emerges - Changez, if he remains in America, must live as an interpellated-self. Hamid's novel provides critical insight into the process of marginalisation. He demonstrates how marginalisation sabotages the possibility for a legal immigrant to fully acculturate into his or her new country and culture. Likewise, he indicates that a person's racial or religious profile is often determined by others. This predetermined profile affects a large demographic in the US, which suggests that preset biases create the opportunity for a person to perform subalternity. Marginalised people, having lost their voice, are unable to change preconceived notions about their personhood and culture. These people, instead, must decide if they will act in accord with the stereotype, or if they should altogether leave America to escape their discrimination. ${ }^{1}$ Accordingly, as Peter Morey points out, even the title of the book foregrounds preconceived biases; in other words, the title draws false conclusions in reader's mind before he or she ever read a page. He notes: "[The Reluctant Fundamentalist] exploits the reader's expectation of what such a text may contain" (139). A reader might assume that the protagonist is a radical fundamentalist, but this conclusion is never directly answered. Instead, the title questions how people ascribe or take away a different person's agency. This aligns with what Stephen Morton says about Spivak's subaltern: "The political voice and agency of particular subaltern groups was often indistinguishable

\footnotetext{
${ }^{1}$ This action correlates with Judith Butler's discussion about the importance of defining and differentiating the ontological effects, as well as the economic underpinnings between an 'illocutionary performative' versus a 'perlocutionary performative' (Butler 148-55). Both terms are placed in conversation, and are debated, via positivism's influence on naturalizstion and marginalisation. As I argue, throughout this paper, Changez mostly operates under the perlocutionary performative; because, the US elite do not allow others the privilege of acting under an illocutionary performative.
} 
from elite characterisation[s]" (Gayatri Chakravorty Spivak 50). The reader, therefore, must consider the connotations and repercussions that labels, such as fundamentalism, impart on an individual. Furthermore, one must question how these caricatures affect the existence of immigrants - those forced into pockets of otherness. Finally, one must examine whether or not preceptive labels affect an immigrant's economic soundness, even if Spivak wants her readers to keep economics as a small "irreducible" factor "under erasure" (35).

Changez, by example, is confronted with the elitist American bias when he meets the family of his love interest Erica (another play on words for (Am) Erica), which is an inspection of the nation's internal deterioration. During a conversation with Changez, Erica's father reveals his "summary [of] some knowledge" about Pakistan that fuels his prejudice: "And fundamentalism. You guys have got some serious problems with fundamentalism" (55). His preconceived ideas are grounded in partial truths that govern his entire perception of fundamental Pakistan. Adnan Mahmutovic mentions that Erica's father "implies that these Non-American peoples, albeit long-standing allies of the US, have no proper selfhood" (8). I suggest that this lack of heterogeneity is not inherent within group; instead, I argue that fragmented identities are superimposed on others by forces outside their control. By example, Changez cannot change Erica's father's ideas about Pakistan; his opinions are fashioned and promoted from the elite down to the American people. Here, I suggest, Changez performs as the voiceless subaltern - he does not correct Erica's father. Changez is ostracised because he cannot change these ill-informed biases about his race, nationality, and religion, which hinder his progression toward Americanisation. Similarly, these forces of partial truth (concerning an entire segment of society) include governmental profiling, censorship, and hate crimes, which are essential elements in the process of marginalisation. Changez's isolation mentally tears apart his conception of true identity, which Moore-Gilbert suggests is flawed essentialism. Concerning Spivak he states, "true" identity wrongfully assumes a self that is rooted in one's sense of "origin or belonging," which, by further explanation, neglects neocolonialism's "role in constructing the identity of its subjects" (86). I believe that a fragmented identity occurs when the question of a rooted identity mixes with neocolonialism's influence. For example, though Changez "was the product of an American University; [and] was earning a lucrative American salary; [and] was infatuated with an American woman," he remains torn about whether or not he belongs in America (The Reluctant 73). He realises that his marginalisation stems from his nationality and his religious 
affiliation, which makes him question his identity. This hybrid-realisation creates the opportunity for him to adopt a performative subalternity, which again, by drawing upon Spivak, does not mean that he is a true subaltern because he knows "the mechanics of [his] discrimination" (Spivak 46). Instead, Changez choses to perform as an in-between person. An example of his spilt identity occurs when he states: "I am not at war with America," yet two sentences later he struggles with uncertainty about why he smiles after 9/11. He confesses that a "part [of him] desire[s] to see America hurt" (73). This suggests that Changez's attempts of acculturation are complicated when forced, on September 11, to be both a Pakistani immigrant and an American worker. This creates the performative subaltern-a division of self.

Alghamdi, in order to understand the purpose of this dichotomy, suggests that Hamid uses his novel as a platform to inform his readers about the reality of marginalisation post-9/11. He claims that the book is partially "educative when directed at the Western reader: for example, Changez points out several times that Pakistan has a long and rich cultural history compared with that of Europe, let alone North America" (53). This educative lesson, I suggest, means to enlighten the reader concerning the paradigm shift that occurred post-9/11. The contours of Changez's marginalisation include emotional alienation, the loss of employment, and denial to certain social spaces. In the periphery, he cannot overturn the misconceptions about his race and religion, which indicates that he is one voice among many who are involuntarily portrayed as radicals. He, like the myriad of others, has to reclaim his immigrant heritage. This decision will inevitably end with isolation, ridicule, and coercion (a Marxist false consciousness). In other words, this decision may force people to unwillingly consent to the hegemonic powers (a Gramscian model), or the marginalised might choose to flee the country. Changez, to reiterate, is not a true subaltern because he is conscious that Islamophobia labels him as other; nonetheless, he performs the role of the subaltern. For example, he questions what to do about his heritage; because, he knows to remain in America, as a voiceless outsider who cannot change Islamophobia, means he must perform as a subaltern (one who adopts the narrative of guilt, shame, and otherness under the national narrative constructed for him). If he decides to leave the US, then he will assume the role of a positional subaltern who goes back to where he comes from - he cannot change the national bias against himself. I suggest that the performative and positional subaltern are connected with each other; for instance, location changes the type of performative subalternity that a person chooses to adopt. If one, therefore, 
decides to live within the constraints of an oppressive culture, then he or she might preform as the helpless victim. If, however, he or she leaves that nation and moves to one of the demonised nations, then the individual might perform as the radical stereotype.

Changez, immediately after 9/11, feels the isolating effects of Islamophobia. A few days after the attacks, when trying to leave Manila to return back to New York City, he experiences the first taste of his new life in America. At the airport he is "escorted by armed guards into a room where [he] was made to strip down to [his] boxer[s]" (74). This extra selective "precaution" makes him the last person to board the plane, which "elicited looks of concern from [his] fellow passengers" (74). The fear surrounding his presence on the aircraft makes him state: "I felt guilty" (74). Instantly, the people on the airplane establish the border of emotional otherness - he adopts a sense of shame for no legitimate reason. America's Homeland Security, just like the people on the plane, clearly place their national borders centerstage. His sense of guilt, for crossing the US border, manifests part of Changez's performative subalternity. This begins his emotional reaction to his marginalisation, which is to say his misplaced sense of shame is predicated upon the reality that people now see him as an other. Attempting to re-enter America's physical border, post- 9/11, creates the platform for performative subalternity. Hart and Hansen discuss border theory by noting that borders are used, in contemporary literature, as a way of "crossing and confounding [...] if not in practice, then, in the [reader's] imagination" (506). This policing is not limited to governments, establishing clear borders on their nation's edges; instead, average citizens also establish borders of otherness. A few of these barriers include emotional borders incited by verbal slurs, physical threats, and the anxiety of identifying as Muslim at a time when the US declares a "war on terror" under the George W. Bush administration (Hartnell 344). The ingredients for a performative subaltern are set in place, and the state, including its people, firmly establish the idea of difference over its predecessor deference. Changez gradually becomes more aware of the belligerent state of America's growing Islamophobia, which eventually, out of defiance, urges him to grow a beard and quit his lucrative job. This is where, I argue, his performative subaltern emerges - an idea discussed by Santesso in Disorientation (2013). Santesso states that Najwa (a character in Minaret), cannot be subaltern because of her class and educational background, yet she "chooses to act like" a subaltern by adopting "the 'silence,' the 'invisibility' and the marginalisation of the subaltern subject" (101). I argue Changez, even though his education and social class prevent him 
from being a true subaltern, adopts the same mentality as Najwa. He embraces the sense of guilt and profiling that America places on him. This classification of performance complicates Butler's views about the social implications of subversion under elite powers. She differentiates between 'illocutionary' and 'perlocutionary' performatives by stating that the former "[relies] on a certain sovereign power of speech to bring into being what it declares, but a perlocution depends on an external reality, and, hence, operates on the condition of nonsovereign power" (151). This suggests, if applied to The Reluctant Fundamentalist, that Hamid provides the reader with a view of how a subaltern group might form. He also shows how a person can perform as a subaltern even if he or she cannot be a true subaltern, which links with the result/aim of performance as dictated by the ruling powers. For example, after hiding his "internal conflict" about his heritage from his boss, Changez thinks about all "the discrimination Muslims were beginning to experience," such as "rescinded job offers and groundless dismissals" (120). Changez later questions the extent of this marginalisation and fear. He realises that discrimination not only impacts the daily existence of Muslims living in America, but he discerns that it stretches beyond US borders as a platform for war. Changez speculates how America can "wreak such havoc in the world [...] with so few apparent consequences at home" (131). This complicates the issue of national borders; insofar as, the ripple effects of a few men invading American borders with malicious intent upsets the normality of life of immigrants living in the US - many of whom have lived peacefully in America for years. Changez, at the same time, meditates on the fact that the US secures its borders by invading other national borders, which they do with even greater destruction and with little to no repercussion on American soil. These realties expose how sovereign powers not only seek to maintain control of their national reality, but how they also attempt to manipulate the realities of immigrants with foreign customs.

On borders, Gloria Anzaldúa states that "Western culture [makes] 'objects' of things and people," which they use to deny the rich cultural heritage and global significance of others (59). This suggests that imperialism lacks interest in learning the robust heritage of those they consider different; instead, outsiders' culture is viewed as a commodity of lesser value. For Anzaldúa, "This dichotomy is the root of all violence" (59); hence, in order to stay secure, US border security is cushioned in violent methods of border crossings that "wreak [...] havok" abroad (ExitWest 131). This aggression aims to not only keep violence afar, but to cement America's global dominance. Such tactics, however, create trouble within the US borders as their myriad of hybrid-citizens are cast into the periphery, which 
demonstrates how overnight a large number of people living in the US were associated with an identity that they could not change. As a repercussion, a major segment of legal citizens living in the US pre-9/11 are now classified, post-9/11, as others via their religion and nationality. The discrimination that immigrants endure, within the US borders post-911, relates to their positionality, which suggests that many legal immigrants feel the effects of marginalisation in the US This positionality suggests that overnight they are viewed as outsiders; whereas, pre-9/11 they were seen as acceptable citizens in the US. They, after 9/11, are viewed as radical foreigners. These unwelcomed people are moved into a voiceless state of existence; one unable to change the elite bias against them within the US. Before I discuss the voiceless immigrant, I must first establish the source of profiling through the lens of national memory and patriotism. Bigotry is a doubleedged sword that damages both those who wield it, as well as those who receive its strike. Lindsay Balfour's "Risky Cosmopolitanism: Intimacy and Autoimmunity in Mohsin Hamid's The Reluctant Fundamentalist" argues that America's idea of a perfect nation began to crumble after 9/11. She continues, "Hamid's novel uses the metaphor of an (Am)Erica in decline to make an extraordinarily provocative suggestion, not simply that America is unable to deal with the transforming realities of the world around it, but that it is effectively dying by its own hand" (214). Her argument is akin with Erica, Changez's love interest, in that her internal deterioration mirrors the growing divide in the US after 9/11. Erica, as the novel moves ahead, becomes emotionally distant to both Changez and herself. The memory of her past lover, Chris, overtakes her life. She eventually mysteriously disappears, which leaves the reader wondering if she committed suicide. In life, however, she tries reliving the past by remembering how wonderful life was with Chris. Her memory of Chris exposes America's sentiment about its lost heritage before 9/11, as well as the fleeting reality that they can never return to the good old days. This longing for a lost memory illuminates that America, if unwilling to let go of the past, will struggle to live in the present. This internal conflict suggests that national memory can be dangerous: it romanticises a past that no longer exists. National memory creates the mirage of a better life- one without the scruples of current events, one without the dangers of people who have different customs, and one without non-Christian religions.

Erica's former relationship exemplifies the danger of romanticising the past for both an individual and a nation. For example, "when Chris died [...] Erica felt she had lost herself; even now, she said she did not know if she could be found" (91). The traumatic event of his death causes a fissure in her identity 
that she cannot overcome, which indicates her identity is rooted in the past. For example, while having sex with Changez, Erica demonstrates her desperation to recover her past — she lets him pretend he is her dead lover (105-6). This implies that she slowly releases her past as she learns to incorporate it with the present. Unfortunately, she remains unwilling to completely let go of her memories. Balfour believes this is a central theme of the novel. Changez questions "what it means to engage with others and strangers in a time of terror" (215). Just as Erica and Changez try to work out their unstable relationship, so must the US realise that it will never be the same as it was pre-9/11. The fact that Erica mysteriously disappears suggests that her fractured identity has no resolution. This, in turn, questions whether or not the US will face a similar fate if they cannot move beyond pining after a memory. If not, then the myriad of hybrid-citizens, like Changez, will never have the opportunity to fully acculturate; because, those with cultural and political power both view and speak about outsiders as other. Changez, consequently, begins to realise that his pre-9/11 dream of becoming a "philosopher-king," in America, will never blossom. He, instead, suffers under the label fundamentalist (3). This correlates with Spivak's theory of 'ideological' constructs that keeps men dominant over the voice and role of women in society; however, in this context the male represents US nationalist propaganda against Islam. The female, by comparison, represents the voiceless immigrant who cannot change these labels (Spivak 41, 57). After 9/11, hysteria precludes the fact that many immigrants have lived in the US for decades without causing terror, yet their non-fanatic history is lost "deeply in [the] shadow" of nostalgia and fear (41). The Reluctant Fundamentalist does not suggest that the very fabric of cosmopolitanism is torn apart as much as it suggests that this fabric never existed. A global community cannot exist when preconceived biases and assumptions reveal themselves after a major traumatic event. The circumstances of 9/11 did not form these bigotries; instead, as Hartnell notes, it brought "an intensification of something that was already there before" (339). Ultimately, Hamid fearlessly discusses biases as a hinderance not only to the global advancement of the US, but he also shows how these assumptions subjugate people who want to live peaceful and successful lives as immigrants within new borders. Quratulain Shirazi addresses this idea when she claims that contemporary diaspora literature interests itself with a break from classical diaspora narratives. She further claims that migrants were historically expected to make a "unidirectional break from [their] homeland... [with] a remembrance [motif] of homeland. However, in the new diaspora context, it is no longer assumed that migrants make a sharp break 
from their homeland" (16). In other words, immigrants bring their customs to their new homeland, which indicates that all people must embrace different heritages for a pluralist society to exist. In his latest novel ExitWest (2017), Hamid expands the idea of a changing world.

The two protagonists Nadia and Saeed, in Exit West, flee their war-torn nation and seek asylum from country to country. They, like Changez, never find a place of absolute acceptance. Instead, their status forces them to live in the margins of society as dwellers in refugee camps. Their relationship slowly dissolves as both characters lose their sense of self - they face extreme social and emotional pressure in the camps. Their struggles are juxtaposed against the backdrop of a glistening western world that thrives from the exploitation of refugees. Unfair taxation (against refugee workers) pour money into the greedy hands of native dwellers who have learned to tolerate the others. The protagonists, because of their exploitation, are constantly on the brink of starvation. Still, the novel presents a few glimpses of the West's willingness to finally understand the effects of discrimination. For example when a wealthy English accountant decides to step through one of the magical doors of migration. After he enters a door, his perspective forever changes because his feelings adjust by ending up in Namibia. (ExitWest 129-30). Before entering the portal, this man was suicidal because the magical door randomly appeared in his house. He feared that foreigners would disrupt his life and routine; however, his outlook changes once he decides to step through the door and live as a migrant. The man, by changing his position, views life from the perspective of those he fears most: the other. His changing perspective, however, is not limited to him alone.

The reader encounters a different instance of morphing perception through an English woman. After migrants pour into London, this woman realises the pivotal truth that "when she went [outside] it seemed to her that she too had migrated, that everyone migrates, even if we stay in the same houses our whole lives, because we can't help it. We are all migrants through time" (209). Her neighborhood, because of the influx of migrants, evolves day to day. Initially she was frightened, however, later she comes to realise that life assumes constant flux. Hamid suggests that all people collectively share stories of suffering and isolation, which ought to unite instead of divide people. This understanding, sadly, is slow to root itself in the minds of westerners - they fear the outsider. ExitWest was published ten years after The Reluctant Fundamentalist, which might suggest that the West is finally at a proper place to challenge and change its perception about others. Nonetheless, The Reluctant Fundamentalist offers no suggestion that 
post-9/11 America views Muslims as anything but an other-one not belonging to their tribe. This, in turn, impedes the possibility, whether good or bad, for immigrants to fully acculturate into their new homeland - even if they are legally positioned within its borders.

Both malice and fear destroy an immigrant's hopefulness to acculturate, which was previously linked with the notion that an immigrant was welcomed in the tribe. The paradigm shift from acceptance to disenfranchisement is what I suggest lends itself toward performative subalternity. By example, Changez moves to the US hoping to achieve the American dream, and in many ways he achieves it; however, in the process of his Americanisation he must reconcile his cultural heritage against the way his difference is categorised "from the elite" (Spivak 39). The elitist opinion, under Spivak's subaltern theory, governs how people are represented or not represented at all. This is not to say that Changez has a "clear-cut [nostalgia] for [his] lost origin;" instead, I suggest that he struggles with the new labels that the elitists establish (62). He, at first, adopts a shortterm solution to his discrimination - he performs as a subaltern by quitting his job and growing his beard. The former responds to elitist bigotry; the latter is strictly out of defiance.

Brygida Gasztold addresses the potential long-term effects of Changez's marginalisation: "the events of 9/11 annihilate the protagonist's immigrant hopes, showing how fragile the foundations of these hopes actually were in American reality. Instead of coming to terms with the new post-9/11 world, America is presented as nostalgic about the loss of innocence" (23). Pining over their past nostalgia, America hinders/prevents immigrants' opportunity for success, - historicising them out of the frame. Changez, at first, believes that he can totally integrate as a civilian, which he does achieve by his success of getting a Princeton education and by landing a job at Underwood Samson. Without a doubt he does thrive in a capitalist nation, yet he fails to realise that nations are built upon the bourgeois exploiting the proletariat and the need for others. Aimé Césaire discusses this concept in Discourse on Colonialism: "It is a fact: the nation is a bourgeois phenomenon" (74). This implies that a nation only exists if there are exploitable others. This does not mean that only some nations benefit from global capitalism; instead, this suggests that some nations enjoy far more privilege than other nations - a few nations dictate the operation of global capitalism. The events of 9/11 serve as the catalyst to further isolate people from the top privileges of capitalist spoil. Gasztold notes that Changez "realises that the corrupt nature of his job and the pursuit of ideals that serve the capitalist system deprive him 
of a vital part of his identity," which is why after 9/11 he begins rejecting the capitalist system that labels him as other (19). This rejection is what causes him to adopt performative subalternity. By growing his beard, Gasztold further notes that Changez makes a "non-verbal statement about post-9/11 America," which "draws attention to himself and his subaltern position, highlighting an individual amidst the global controversy" (24). His "non-verbal" attack against his new fundamentalist label is important because it suggests that the elite will not listen to his vocal concerns, which is why he performs as a voiceless subaltern. Changez leans into the prescribed narrative. He realises that Islamophobia has taken strong root, which is why, within US borders, it is impossible for him to verbalise his concerns about his classification. His racial and religious profile isolate him from society, which deepens the contours of his marginalisation: both the social and emotional. Hence, he realises the futility of trying to erase America's growing Islamophobia. His awakening, I suggest, is where his voiceless nature emerges. One might argue that the act of growing his beard is an example of "voiceconsciousness," which argues for a realised subalternity. I agree that Changez's actions consciously address the burgeoning stereotype; however, I too posit that this non-verbal action is a performative statement against hegemony. By way of clarity, I am suggesting that Changez embraces a sense of guilt associated with his label. He draws attention to what Morton says about subaltern labeling: "everyday lives and identities are defined in and through dominant social structures that are relatively autonomous of economic relations" (Gayatri Chakravorty Spivak 65). Changez understands and leans into these false assumptions. His performance directly links with his positionality in the US, which is to say that he can only make voiceless gestures against isolation and bigotry while living under their "dominant social structures" (16). Thus, his position in the US only permits voiceless expressions of performative subalternity; however, Changez's performance changes when he positions himself outside the US.

The Reluctant Fundamentalist unapologetically diagnoses both the causes and effects of marginalisation. A fascinating aspect of this discourse questions whether or not locality alters the extent of marginalisation. For clarity, it is important to note that post-9/11 America does not argue for the erasure of immigrant culture; instead, the America elites, via culture, politics, and economy, believe that their way of life is the archetype of civilisation. Therefore, those who do not fit into the US mold are labeled as others. This is why Ingrida Žindžiuvien argues that Hamid consciously creates a trauma narrative that "recreat[es] the events" of traumatic experiences, so that "readers and critics [can] gain access to 
the extreme events and experiences" of marginalsed people (149). This implies that Hamid intentionally first details the normalcy of Changez' life before 9/11, so as to provide an insider view of the dramatical change in Changez's life after the trauma of $9 / 11$. Hamid skillfully portrays the genesis of marginalisation by recreating the extreme conditions that millions of people faced in the days, weeks, and years after the attacks. For example, the narrative discusses the dislocation and the rupture of a cosmopolitan culture, which manifests itself through the use of Underwood Samson as a capitalist company built on exploitation, the disintegration of (Am)Erica's relationships, the forced narrative of Changez as a "Fucking Arab" (even though he is not an Arab), and the unresolved questions of both Erica's suicide and Changez's possible death. Žindžiuvien, later in her essay, uses Mariejanne van Dijk to argue that these traumatic events are designed to show the reader how Changez, as an immigrant, slowly loses his dream of acculturation. His loss further kills his respect for everything about the nation and himself (151). Changez is caught in the fringe. He loses both his sense of cultural origin and his new American identity, which is why he decides to leave America. He is able to perform as a subaltern because he has no sense of origin to feel nostalgic about, nor does America accept him as an elite member of their society.

Changez's struggle for peace and continuity are the main reasons why he decides to leave his job at Underwood Samson, as well as his choice to leave America. Immediately after 9/11, he is quickly shamed and labeled as an outsider by the society he idolises, and he realises that the elitist US narrative will not waiver from its position. His voice will not change the discourses about the growing threat of imperialism, the mounting pressures of being a Muslim minority in America, nor the dangers of waging a war on terror based on racial and religious profiling. By leaving, Changez combats his voiceless ostracisation in America, but he reinstates his voice against these dangers after he is outside the United States. Victoria Kuttainen's essay on trauma and border crossing helps one understand why a character like Changez leaves America: "The topic of trauma is pertinent to the issue of border crossing because trauma itself is primarily about boundary trouble" (33). The World Trade Center attackers visualise this type of border trauma, which also magnifies the trauma Changez faces when he tries to re-enter the US after the attacks. He again experiences emotional trauma when he leaves the US for the last time — he is now an outsider. Changez addresses his marginalisation by returning to Pakistan as a university professor. In this role, Changez teaches his dissident students about the ills of imperialism, 
and he aids their protests against technocracy. His rebellious attitude gains him favour with his students (approval not achievable in America by teaching the same material), yet his lessons and political involvement elicit stern warnings from his department.

One must remember that Changez, while in America, can only make voiceless gestures against imperialism. By contrast, in Pakistan he joins the conversation against America's racial profiling, but this is only possible once he is outside American borders. Even though he changes location, he still performs as a subaltern. In America, Changez leans into the elitist narrative and feels shamed by his background; however, in the East he performs as a subaltern who bashes America from afar. His teachings, therefore, feed the anti-Islamic rhetoric that all Muslims desire the destruction of the US. His activism gains the attention of the US government who answer his harsh rhetoric by sending a possible assassin to kill him (this is left up to the reader's imagination). I believe this attention gestures toward the idea that he is performing as a subaltern; in that, the elite send an agent to deal with his problematic voice - a voice that consciously speaks of their elitism and profiling. I do not disagree that Changez's consciousness of his profiling and American discrimination proves that he not a 'true' subaltern; however, his realisation is why I suggest he merely preforms as one. This, I argue, is the key component of the entire book. Changez can only voice his disgust once he is far enough away from the people who write his story in their terminology. Changez's actions reveal that his positionality determines the type of subalternity he performs, which suggests that location dictates if he operates and is viewed as a helpless victim, or if he performs under the assumption that all Muslims are radicals.

Questions about borders and positionality are relevant because they force one to identify with one nation, one party, one religion, or one race when in reality a person may be multifaceted. Gloria Anzaldúa details the methods nations use to control their sense of homogeneity. She discusses the tribal mentality of societies, which are the ideologies and practices (religious, sexual, and political) a nation uses to preserve its image and zeitgeist. She also notes that deviants (those considered unacceptable to the norm) are identified and persecuted (3840). This blurs the viscosity of borders; in that, do biases transcend borders, or are these prejudices stuck within the constraints of any given nation? Does one's location determine the type of performative subalternity that he or she adopts? I suggest that the type of performative subalternity a person embraces depends on his or her economic well-being. Even though Spivak is leery of 
strictly connecting subalternity with economics and class struggle; I believe that these categories are non-restrictive in relation to performative subalternity (Morton, Ethics 111; Morton, Gayatri Chakravorty Spivak 45; Moore-Gilbert 107; Spivak 33-5). In America, for example, Changez's survival depends upon what Spivak says is a person's ability to work and access "the culture of imperialism" (Kock 46). The reality that Changez does in fact, before 9/11, have access to "the culture of imperialism" discredits him from being a true subaltern. After 9/11, however, Changez performs voiceless acts of aggression that consent to the narrative constructed for him by the elite, which isolates him from advancing further economically. His access to "the culture of imperialism" is severely minimalised. These actions gesture toward the fact that he is not a subaltern, but that he both adopts and performs as one. In Pakistan he performs the role of a subaltern by leaning into the part of a radical, which does not make him lose his job as a university professor-his financial stability is not under threat in Pakistan as it was in the US. Nonetheless, the American government views him as a threat, but only when they learn about his radical teachings. His lessons do not act in accord with the official narrative: a story the US constructs about radical fundamentalism. One may argue that this is just religious profiling from afar; however, if a person's direct economic stability is threatened because he or she deviates from the official elitist narrative (as surely would have happened if Changez taught anti-American propaganda in the U.S), then I would say this is not an act of subalternity because he or she does not consent to the official narrative regardless of persecution. Yet, if this person does not verbally rebuke their situation, even if they instate voiceless acts of aggression because of feeling unwarranted guilt, then this person might be performing as a subaltern. The elite will not permit a subaltern to speak against the narrative they construct. This is what I have defined as the performative subaltern. I am suggesting that borders play a pivotal role in a person's decision to adopt the persona of subalternity, even without actually being a subaltern. I imply that economics foster the type of performance this person may choose to adopt: either to consent or to retaliate. This begs the question about whether or not a pluralistic society is possible. Hamid understands this disconnect of personality, for he mentions that Changez "is torn because on the one hand he is quite in love with America and is doing quite well in America, but on the other hand he feels a kind of strange tribal affiliation that says he is happy America is hurt" ("Q\&A”). The reader is not angry that Changez feels the way he does; in fact, by the end of the novel he or she is able to understand why he has this "tribal affiliation" with those isolated post- 
9/11. Changez's indignation relates to what Anzaldúa calls the "Shadow-Beast," which "is a part [of those marginalised] that refuses to take orders from outside authorities [...] [something] that hates constraints of any kind," and she mentions how this person resists these constraints by "kicking out with both feet" (38). Changez's shadow-beast refuses to accept the elitist narrative about himself. His counter-narrative makes it emotionally impossible for him to fully become accepted as an acculturated citizen. Instead, he rebukes America's unwillingness to listen to his truth about nationalism and patriotism, which he only does once he relocates. The novel, however, does not let the reader merely sympathise with Changez; the reader is forced to question his or her own bias. Changez says that it is wrong to assume that all "Pakistanis are all potential terrorists, just as we should not imagine that [all] Americans are all under-cover assassins" (183). The end of the novel calls upon the reader to resist the temptation of making assumptions about someone's identity. By example, Changez refuses to believe the American (with whom he has been eating) is an assassin sent to kill him. He uses this logic to try and convince the American against this same impulse: Changez attempts to persuade the American against the pre-conceived idea that all Muslims are extremists.

The Reluctant Fundamentalist, by way of summary, uses key motifs to confront marginalisation and borders. The attacks of 9/11 served a crippling blow to millions of Muslims living in America, which forced many people into the periphery and some toward a performative subalternity. This push toward performative subalternity is the result of an elitist culture that constructs the narrative for other nations and religions. The novel scrupulously portrays the substantial shift in Changez's life before the attacks, so as to highlight his life after 9/11. The book questions whether pluralism is feasible — what catastrophic event will inevitably spiral a society into a new type of discrimination for a different group of people? The polarisation of Changez, throughout the novel, suggests that national borders cause millions of people to live fragmented lives of either compliance or extremism. Can true hybridity exist when people feel the pressure of acculturation or dissociation? Hamid's novel applies to any group of immigrants who are ostracised because of who they are or what they believe. Similarly, the book addresses the destructive power that official narratives create within a nation's borders; likewise, the novel reveals that fabricated narratives cause issues afar. Changez's story forefronts the issue of assuming other's identities for them, and his experience questions how borders are both defined and crossed.

Ten years after publishing The Reluctant Fundamentalist, Hamid seems to suggest, in 
ExitWest, that people are becoming increasingly aware of their biases. Similarly, he presents the notion that people are beginning to realise the danger of fashioning a story for those labeled as other. He reminds his reader: "We are all migrants through time" (Exit West 209). Perhaps this means there is no longer the need to discuss performative subalternity and positionality; however, I believe that the warnings present in The Reluctant Fundamentalist are as strong now as they have ever been. The fact that Changez even has the option to perform as a subaltern is a sad reminder that millions of people faced the same struggle - they were forced into pockets of exclusion post-9/11. Changez, because of his marginalisation, loses touch with reality. The events of $9 / 11$ created an opportunity for the elite culture to fashion false narratives about those they viewed as others. This generated the occasion for Changez to undergo an identity crisis and he decided to perform the role given to him by the elite culture. It is important to not forget that Changez only finds his voice once he moves out of New York City. Also, one must remember that the US government saw his counternarrative as a threat that needed silencing, even when he was outside the borders of the United States of America-lines that may soon become even more visible on the Mexican/American border. Such a reality raises a major question concerning elitist patriotism and immigration: will the Mexican-American be the next to perform subalternity?

\section{Works Cited}

Alghamdi, Alaa. "Shifting Positions: Identity and Alterity in The Reluctant Fundamentalist." IUP Journal of English Studies 8.1 (2013): 51-67. EBSCOhost. Web. 25 July 2016.

Anzaldúa, Gloria. Borderlands La Frontera:The New Mestiza. San Francisco: Aunt Lute Books, 2012. Print.

Balfour, Lindsay Anne. "Risky Cosmopolitanism: Intimacy and Autoimmunity in Mohsin Hamid's The Reluctant Fundamentalist." Critique 58.3 (2017): 214-225. Print.

Butler, Judith. "Performative Agency." Journal of Cultural Economy 3.2 (2010): 147-161. EBSCOhost. Web. 25 July 2016.

Césaire, Aimé. Discourse on Colonialism. Trans. Joan Pinkham. New York: Monthly Review Press, 2000.

Gasztold, Brygida. "Of Promises Delivered and Failed: Post-9/ 11 America through the Eyes of The Reluctant Fundamentalist by Mohsin Hamid." Ad Americam 16 (2015): 17-28. Web. 15 Jan. 2015. 
Hamid, Mohsin. ExitWest. New York: Riverhead Books, 2017. Print.

---. The Reluctant Fundamentalist. New York: Houghton Mifflin Harcourt, 2007. Print.

Hart, Mathew, and James Hansen. "Introduction: Contemporary Literature and the State." Contemporary Literature 49. 4 (2008): 491-513. EBSCOhost. Web. 15 Jan. 2015.

Hartnell, Anna. "Moving through America: Race, Place and Resistance in Mohsin Hamid's The Reluctant Fundamentalist." Journal of Postcolonial Writing 46. 3 (2010): 336-348. EBSCOhost. Web. 15 Feb. 2015.

Kock, Leon De. "Interview with Gayatri Chakravorty Spivak: New Nation Writers Conference in South Africa." ARIEL: A Review of International English Literature 23.3 (1992): 29-47. EBSCOhost. Web. 10 Aug. 2015.

Kuttainen, Victoria. "Boundary Trouble: Trauma Fiction and Postcolonialism Tim Winton's The Turning." Border-Crossings: Narrative and Demarcation in Postcolonial Literatures and Media. Ed. Russell West-Pavlov et al., Heidelburg: Winter, 2012. 33-44. Print.

Mahmutovic, Adnan. "Global Citizenship in Mohsin Hamid's The Reluctant Fundamentalist.” Transnational Literature 8.2 (2016): 1-15. ProQuest. Web. 10 Nov. 2016.

Morey, Peter. “'The Rules of the Game Have Changed': Mohsin Hamid's The Reluctant Fundamentalist and Post-9/11 Fiction." Journal of Postcolonial Writing 47.2 (2011): 135-146. EBSCOhost. Web. 10 Aug. 2014.

Morton, Stephen. Gayatri Chakravorty Spivak. London: Routledge, 2003. Print. ---. Gayatri Spivak: Ethics, Subalternity and the Critique of Postcolonial Reason. Boston: Polity, 2007. Print.

"Q\&A Highlight - Mohsin Hamid on 'The Reluctant Fundamentalist'. Online video clip. YouTube. You Tube. 18 May 2015. Web. 26 Aug. 2016.

Santesso, Esra Mirze. Disorientation: Muslim Identity in Contemporary Anglophone Literature. London: Palgrave, 2013. Print.

Shirazi, Quratulain. “Ambivalent Identities and Liminal Spaces: Reconfiguration of National and Diasporic Identity in Mohsin Hamid's The Reluctant Fundamentalist." South Asian Diaspora 10. 1 (2017):15-29. EBSCOhost. Web. 10 June 2017

Spivak, Gayatri Chakravorty. "Can the Subaltern Speak?" Can the Subaltern Speak?: Reflections on the History of an Idea. Ed. Rosalind C. Morris, New York: Columbia UP, 2010. 21-78. Print. 
Žindžiuvien, Ingrida Egl. "Rambling Confessional Narrative in Mohsin Hamid’s Novel The Reluctant Fundamentalist." Procedia - Social and Behavioral Sciences 158. 14 (2014): 147-154. EBSCOhost. Web. 10 Aug. 2015. 